\title{
What Kind of Islamophobia? Representation of Muslims and Islam in Italian and Spanish Media
}

\author{
Laura Cervi $^{1, *}$, Santiago Tejedor ${ }^{1}\left(\mathbb{D}\right.$ and Monica Gracia ${ }^{2}$ \\ 1 Department of Journalism and Communication Sciences, Autonomous University of Barcelona, \\ 08193 Bellaterra, Spain; Santiago.Tejedor@uab.cat \\ 2 Faculty of Social Science and Humanities, Universidad Europea del Atlántico, 390211 Santander, Spain; \\ monica.gracia@uneatlantico.es \\ * Correspondence: Laura.Cervi@uab.cat
}

Citation: Cervi, Laura, Santiago Tejedor, and Monica Gracia. 2021. What Kind of Islamophobia? Representation of Muslims and Islam in Italian and Spanish Media. Religions 12: 427. https://doi.org/ $10.3390 /$ rel12060427

Academic Editors: Chris Allen and Christina Verousi

Received: 25 April 2021

Accepted: 2 June 2021

Published: 9 June 2021

Publisher's Note: MDPI stays neutral with regard to jurisdictional claims in published maps and institutional affiliations.

Copyright: (c) 2021 by the authors. Licensee MDPI, Basel, Switzerland. This article is an open access article distributed under the terms and conditions of the Creative Commons Attribution (CC BY) license (https:// creativecommons.org/licenses/by/ $4.0 /)$.

\begin{abstract}
News media play a crucial role in the production and reproduction of stereotypes, influencing public opinions regarding different groups and minorities. Thus, acquiring a deeper understanding of media coverage of Muslims and Islam is decisive for understanding the sources of public attitudes towards Muslims. This study aims at displaying how Muslims and Islam are represented in Italian and Spanish media. Focusing on the online version of the two most influential newspapers in each country (El Mundo and El País for Spain and Il Corriere della Sera and La Repubblica for Italy) from 2015 to 2020, the results show how Muslims in both countries are mostly framed either related to terrorism or within the general discourse on immigration. In both cases, they are portrayed as "others". The article also presents a novelty, defining and observing two different types of Islamophobia, Banal and Ontological Islamophobia.
\end{abstract}

Keywords: Islamophobia; Islam; Muslims; media; representation; content analysis; Italy; Spain

\section{Introduction}

Islamophobia is a contested concept (Allen 2010a).

Many scholars do not accept the concept, and even among those who adopt it, there is no common definition of exactly what Islamophobia is (Bleich 2011; Larsson and Sander 2015).

This lack of a common definition, and often of a common understanding, makes it hard to compare surveys and attitudinal investigations concerning anti-Muslim sentiments (Larsson and Stjernholm 2016).

Nonetheless, acknowledging this inherent limitation, as Javier Rosón Lorente sagaciously points out, "no matter what we call it, there are acts and attitudes against the Islamic and Muslim communities" (Lorente 2010, p. 117). As stressed by the last "European Islamophobia Report" (Bayrakli and Hafez 2020), most surveys indeed suggest that, independently of the different definitions, anti-Muslim sentiments are on the rise across Western countries.

A vast body of scholarship has tried to understand the reasons behind this growth, pointing at different factors, amongst which an increased Muslim presence (Allievi 2006) and/or political interest in constructing an "Islamic threat" (Cervi and Tejedor 2021; Allen 2010a, 2010b), has capitalized on the growing fear of Islam, particularly since 9/11 (Cesari 2010).

Acknowledging that public attitudes might spring from different sources (Cesari 2011), it is crucial to recognize media's central role in the production, reproduction, and distribution of ideologies (van Dijk 1987) apace with their influence on public opinion (Boomgaarden and Vliegenthart 2007, 2009), voting behavior, and policy preferences (Saleem et al. 2017; Merolla et al. 2013).

Thus, acquiring a deeper understanding of media coverage of Muslims and Islam is decisive for understanding the sources of public attitudes towards Muslims. 
Previous studies have almost unanimously concluded that mainstream media portray Islam and Muslims in a negative way (Ahmed and Matthes 2017). However, as pinpointed by Ahmed and Matthes (2017), besides a general lack of comparative research, most of the studies analyze English-speaking media and/or concentrate on the United States or Northern and continental European countries.

Our study aims at filling both the lack of comparative research and the need to look behind the Anglo-Saxon world by looking at representations of Muslims and Islam in Italian and Spanish media.

The selection of these countries responds to multiple criteria. On the one hand, both countries are "newcomers of immigration" (Allievi 2006) and, due to their geographical position, together with other countries, such as Greece, were at the center of the so-called "refugee crisis" in 2015. On the other hand, while Italy displays high rates of anti-immigrant (in particular anti-Muslim) attitudes (Pew Research Center 2019) and is home to one of the most successful Islamophobic radical right-wing populist parties (Testa and Armstrong 2012) in Europe, in Spain, immigration has traditionally lacked saliency in the political debate, at least until 2018, when the far-right Vox party reached parliamentary representation (Turnbull-Dugarte 2019).

Last but not least, whereas Spain has experienced two "Islamic" terrorist attacks (Madrid 2004; Barcelona 2017) in recent years, Italy is considered an "exception" (Beccaro and Bonino 2019) for being one of the few European countries never (successfully) targeted by this type of terror act.

Focusing on the online versions of the two most influential newspapers in each country (El Mundo and El País for Spain and Il Corriere della Sera and La Repubblica for Italy) from January 2015 (marking the beginning of the so-called "refugee crisis") to January 2020 (before the beginning of the COVID-19 pandemic), this study not only contributes to the burgeoning literature on media representations of Islam by displaying how Muslims and Islam are represented in Italian and Spanish news outlets, but also presents a novelty factor, exploring the existence of different types of Islamophobia.

\section{Theoretical Framework}

\subsection{Islam in Western Media}

Numerous scholars have investigated the representation of Muslims and Islam in different media and across varying geopolitical contexts; the great majority amongst them have retrieved negative representations (Ahmed and Matthes 2017).

In particular, the central dynamics of these representations seem to pivot around securitization, portraying Islam as a violent religion (Ahmed and Matthes 2017, p. 219) inherently connected to terrorism and/or othering, presenting Muslims as an undifferentiated "other" to Western culture (Sunar 2017).

Samaie and Malmir (2017) stress how Muslims in the media are associated with violence and portrayed as "radical Islamists and Islamic militants" (p. 7). In the same vein, Nickerson's (2019) findings in the U.S media's portrayal of terrorist events in France and Turkey confirm that "news media framing utilizes biased, negative imagery ... in a way that reinforces current prejudices against Muslims, even when Muslims are themselves the victims" (p. 547).

Various studies have also highlighted that, when reporting about terrorist acts perpetrated by Muslims, media seamlessly use terms such as "Islamic fundamentalism", "Islamic extremism", and "Islamic radicalism" (Corbin 2017), while, when reporting terrorist acts committed by non-Muslims, they tend to choose more cautious descriptions such as "hate crime", rather than talking about "domestic terrorism" (Marusek 2018).

On the other side, as Allen (2010b) states, media appear to reinforce otherness, reporting Islam as "profoundly different". In this regard, Baker and colleagues (Baker et al. 2013) studying British newspapers have found that Muslims are depicted through emphasizing their sameness to each other and "their difference to the West" (p. 255). To test these findings, Bleich and van der Bleich and Veen (2018) comparatively investigated whether 
Muslims were portrayed more negatively than other religious groups in US media, discovering that the average tone of articles about Muslims is considerably more negative compared to other groups.

In conclusion, not only do most studies agree that both Islam and Muslims are framed negatively, but also most of them point fingers at the inappropriate journalistic language used to describe both Islam and Muslims (Younes et al. 2020; Ragozina 2020; Ewart et al. 2018).

The scarce body of research dealing with Spanish (Alcaraz and Politzer 2020; Corral et al. 2020; Observatorio de la Islamofobia 2018) and Italian (Colombo 2018; Marzano 2011) media seems to uphold these findings.

However, other studies openly criticize (Richards and Brown 2017) or at least soften this vision, negating the existence of "uniformly Islamophobic media" (Flood et al. 2012, p. 255).

Bowe et al. (2015), observing stories about Muslims collected from large circulation newspapers in the United States, proved that a majority of stories contained neutral frames, while approximately $24 \%$ contained negative frames and $4 \%$ contained positive frames (Bowe et al. 2015, p. 51).

Flood and colleagues (Flood et al. 2012), after conducting an extensive study of Islamrelated items on three evening news programs (BBC1, France2 and Russia's Channel 1), determine, for example, that "the BBC exhibited an admirable desire to frame domestic terrorism in impartial terms which guarded against any automatic assumption of Muslim involvement in terrorist incidents" (p. 244). The previously mentioned study by Baker et al. (2013) notes that the majority of the analyzed media took variables such as ethnic/national identity, culture, and group/organizations into consideration.

In the same vein, Munnik (2017) challenges the common idea that all media misrepresent Muslims, showing the case of Glasgow's media, where journalists provide a diverse representation of Muslims, engaging with different Muslim sources. Bleich and colleagues (Bleich et al. 2018), in their analysis of British, American, Canadian, and Australian newspapers between 1996 and 2016, note that, when reporting about devotion in Islam, the media display a more balanced portrayal of Muslims.

Other works find a positive correlation between the media's political ideology and their representation of Muslims: Ghauri and Umber (2019) for example, demonstrate that, in Australia, left-leaning media tend to portray Islam more positively, while conservative outlets frame it through "securitization" and "othering".

In order not to fall into the "growing penumbra" of unprecise and ideologically motivated studies described by Richards and Brown (2017), before proceeding, it is important to distinguish what Islamophobia is (and what is not).

\subsection{What Kind of Islamophobia?}

The origins of the term Islamophobia are difficult to locate. In Europe, the term began gaining popularity in the early 1990s, indicating discrimination against the resident Muslim population (Allen 2010a). However, it is after the publication of the Runnymede Runnymede Trust (1997) and particularly in the post 9/11 period (Bravo López 2011) that Islamophobia becomes a "contested concept in the public space" (Allen 2010a). of reasons.

The concept, in fact, is far from being universally accepted and is rejected for a variety

On the one hand, we find what Lorente (2010) names "racial criticism". Some scholars consider that, since the target of hostility in the modern era is not Islam as a faith and rather Muslim people, the concept does not add to what is already covered at a semantic and even legal level by the term "racism", and they accordingly suggest the use of "AntiMuslimism" (Halliday 1999), or "anti-Arab racism" (Salaita 2006). Accordingly, others rebut the term for not being sufficiently quantifiable, thus not apt for empirical measurements (Imhoff and Recker 2012).

Some voices, including Richardson (2009), reject the use of the suffix 'phobia' in the concept, since it would imply the existence of a sort of mental illness (phobia: obsessive 
aversion to someone or something and/or compulsive irrational fear). Probably the most vivid criticism of the use of Islamophobia comes from those who understand it as a derogatory term for the legitimate and enlightened critique of certain religious traditions, habits, and beliefs. In other words, according to this approach, by using the concept of Islamophobia, we could run the risk of confusing legitimate public criticism of certain religious practices of Islam with prejudiced views, ultimately censoring any option to criticize Islam from a secular perspective (Malik 2009). According to Özyürek, certain practices should be criticized "not because they are non-Christian but because they represent a culture that promotes extreme submission to religion and, hence does not allow individuals to subscribe to secularist values" (Özyürek 2005, p. 510).

According to Halliday, the term runs the inherent risk of "denying the right, or possibility, of criticisms" (Halliday 1999, p. 899). This last position became particularly popular in Europe in recent decades. Two main events especially sparked the debate on freedom of speech versus freedom of religion, particularly concerning Islam: the Mohammed caricatures controversy following the publication of the infamous "Mohammed cartoons" by a Danish newspaper in September 2005, and the terror attack on the satirical magazine Charlie Hebdo in Paris, in January 2015.

From an opposite standpoint, Rebecca Gould (2019) refuted the use of the term Islamophobia, maintaining that it could contribute to the normalization of the securitization of Muslims.

The academic debate among those who accept this concept can roughly be summarized in two broad approaches (Bravo López 2016, p. 1): the first frames it as a type of religious intolerance and the second as a form of cultural racism.

According to the first approach, Islamophobia can be considered as the rejection of anyone perceived as belonging to Islam, based on an assumption that "the individual and collective behavior of Muslims is determined, above all, by religion" (Khader 2016, p. 17), and that this religion is inherently connected with violence and fanaticism.

According to the second and most prominent approach, Islamophobia is a form of cultural racism based on the racialization of Muslims (Carr and Haynes 2015; Garner and Selod 2015). Pairing with Étienne Balibar's description of "racism without race" (Balibar 1991), a racism that has turned its attention from biological to cultural traits, Islamophobia can be considered as a form of racism in which the constitutive antagonism is directed at any "manifestations of Muslimness" (Sayyid 2018, p. 422).

In any case, the attitude of those who consciously or unconsciously position themselves against Muslim communities in a prejudiced manner needs to be named, but most importantly described and defined to be properly studied.

For this reason, rather than of a single phenomenon, it would probably be more appropriate to speak, as Sayyid (2018) suggests, of different "Islamophobias".

Accepting the existence and coexistence of different Islamophobias, to reach our analytical purpose of understanding how Islam and Muslims are depicted in the media, an operative definition is needed. In particular, this definition should be functional to the isolation of specific linguistic/discursive markers of Islamophobia and the understanding of different types of Islamophobia.

To build such a definition, it is crucial to note that, despite the differences, all the mentioned approaches share some common denominators which allow for the outlining of a minimal definition of what Islamophobia is: (1) it is indiscriminate (Bleich 2011), that is to say, it is based on reification (the interpretation of Islam and Muslims as a whole, a monolithic block, neglecting differences); (2) it is a negative vision (Bleich 2011), according to which Muslims and Islam are perceived as separate and "other" from Western culture (Runnymede Trust 1997), and therefore as a threat to be defended against (Bravo López 2011).

Thus, recognizing that Islamophobia is multidimensional and that Islam and Muslims are often inextricably intertwined in both individual and public perceptions (Bleich 2011), by recurring to both abovementioned approaches and classic—Said's Orientalism (Said 1978) 
and Huntington's "clash of civilization" (1996) theories-it is possible to distinguish two types of indiscriminate negative vision. That is to say that there two types of Islamophobia, identifiable by their preferred (not unique) target.

Accordingly, we define Banal Islamophobia as the form of Islamophobia rooted in Orientalism that mainly tackles Muslims and reifies whoever is (correctly or not) identified as Muslim, based on that "Eurocentric prejudice against Arab-Islamic peoples and their culture", portraying them as primitive, irrational, violent, despotic, fanatic, and essentially inferior to the Westerner, described by Said (1978). In this sense, this type of Islamophobia is a form of cultural racism that overlaps with Arab-phobia (Khader 2016), since the ascription of someone into the "Muslim" category entirely depends on stereotyped physical or cultural traits.

Lorente's study (2010) in the Spanish context, for instance, shows that, whereby most immigrants from the Maghreb and Senegal are actually Muslim, the first (especially Moroccans) are immediately recognized as such, as "Moros, and are therefore discriminated against, while people do not tend to establish a direct relation between "Black" Senegalese individuals and Muslims.

Along the same lines, hardly ever would a woman perceived as white and dressed in a "Western" way be a victim of this kind of intolerance.

Therefore, we name it "Banal" not because it functions as a softer or less dangerous form of Islamophobia (Cervi 2020) but because it entails a form of negative stereotyping of anyone deemed "other". On the one hand, it is not different from any other form of xenophobia or racism targeting any individual/community considered as alien/outsider/not belonging to the community of reference (xenophobia, Romaphobia, etc.) (Cervi and Tejedor 2020). On the other, like any other form of cultural racism, it targets individuals, in this case Muslim bodies (Alietti and Padovan 2013).

As such, this type of prejudice leads to the differentiation between "the good Muslim", represented as secular, moderate, rational and, in a word, Westernized, and the "bad Muslim", depicted as fanatical and backward (Mamdani 2004), correspondingly implying that Muslim individuals can be "saved" and integrated, teaching them how to renounce their "traditional" and "backward" values and embrace "contemporary" and "progressive" Western ideas.

Ontological Islamophobia, combined with Allen's (2020) conceptualization of Ideological Islamophobia, refers to a type of Islamophobia grounded on the "clash of civilization" theory (Huntington 1996). Ontological Islamophobia does not target Muslim bodies, rather Islamic civilization as a whole, considered ontologically incompatible with the core values of the West (Cesari 2011) and, as such, dangerous to the very survival of Western civilization. This type of Islamophobia also entails the reification of Muslims and the neglecting of difference, and leads to a different output which considers Islam and the entirety of "Islamic civilization" as inherently violent and fanatic, thus neglecting any possibility of dialogue and, ultimately, co-existence.

\section{Methods}

This study looks at mainstream media, understood as the least likely to engage in sensationalism (Bleich and Veen 2018).

News outlets have been selected based on their readership, influence, and different political perspectives to obtain a more representative sample of political ideologies (Ghauri and Umber 2019; Cervi 2019).

Accordingly, the online version of the two most read and influential conservative and left-leaning newspapers have been selected, respectively: conservative El Mundo and left-leaning El País for Spain and Il Corriere della Sera and La Repubblica for Italy.

Choosing two newspapers with more conservative and more left-leaning editorial policies from two countries allows for the uncovering of patterns which differ in national context and political orientation. 
The time frame chosen is five years, starting on 1st January 2015, marking the peak of the so-called "refugee crisis", and ending on 1st January 2020, before the beginning of the COVID-19 crisis that has caught media attention worldwide, displacing all other major topics (Tejedor et al. 2020).

From a contextual perspective, the selected period is marked, on the one hand, by the Syrian civil war, the rise and fall of the Islamic State and the so-called "Caliphate", and the subsequent migratory wave; on the other, by a series of terrorist attacks inside Europe: Charlie Hebdo and Bataclan in Paris (2015), Brussels bombings, and the Nice truck attack in 2016, as well as the Barcelona attack in August 2017.

The study has followed a mixed-method approach, combining quantitative and qualitative, computer-assisted, and human content analysis. Content analysis is widely considered among the most useful approaches for analyzing news products (Riffe et al. 2014); pairing computer-assisted and human coding techniques is particularly efficient (Bazeley 2010), as the former is more suitable for analyzing large corpora while the latter appears better fitted to isolate contextual cues.

The corpus was built through a keyword search of the words Islam, Islamic Mus$\mathrm{lim} /$ Muslims in both languages in LexisNexis, as well as the newspapers' digital archives.

Only full articles were selected; videos, summaries, and reviews of books were excluded.

First, the entire universe of articles containing one or more keywords $(n=23.988)$ was submitted to a "data cleansing" procedure in which duplicate and off-topic pieces (such as an interview with an economist called Islam) were excluded.

The resulting universe of news articles was downloaded and categorized by name of the newspaper, article's authorship, date, headline, and content.

In a second phase, the retrieved articles were categorized by section (international, national, local, etc.) and by "type", distinguishing between hard and soft news.

Hard news is typically used to refer to topics that are usually timely and important, such as politics, international affairs, etc., while soft news includes topics such as society, entertainment, culture, and lifestyle (Newman et al. 2016).

The following sub-categories were accordingly established: international hard news, national hard news, local hard news, and soft news.

The entire sample of newspaper articles $(n=28,876)$ was analyzed using NVivo, a data analysis computer software package to retrieve: (1) word co-occurrence, (2) most recurrent topics, and (3) most recurrent places, institutions, and public figures.

In a later stage, a sample was selected for qualitative analysis.

The systematic sampling technique is widely considered a better option for providing precise estimators than simple random sampling (Sayed and Ibrahim 2018). Accordingly, using the Kth selection technique, the "sample frame," or 23.988 retrieved articles categorized according to date and section, were divided by the "desired sample size", resulting in 1 in every 20 articles bein selected as a sample.

This technique ensured that the sample was representative of the overall distribution of articles across sections and time in each newspaper.

The obtained sample of 1200 articles was thus analyzed using communicative content analysis. Communicative or dialogic (Rafi 2020) content analysis applies the postulates of dialogic co-creation of knowledge, which recognizes both subjective and objective interpretation, implementing consensus, dialogue, and the equal epistemological level of researchers (Cervi and Roca 2017a, 2017b).

Six graduate students, recruited based on linguistic skills, intercultural attributes, gender, and religious diversity, served as coders. Three of them identify as female and three identify as males. Two of them are Spanish, two Italian, and two Egyptian; two identify as Catholic, two as Muslim, and two as non-religious; all have a working knowledge of at least one of the two languages. 
Coders analyzed both headlines and articles using spreadsheets composed of a series of questions, answerable with a yes or no. They also had the task of noting down words, sentences, or expressions to be discussed in weekly meetings, held over eight months.

Although the following communicative content analysis consensus was reached through dialogue, all inter-coder reliability test results met the kappa $=0.80$ standard set by Krippendorff (2004).

The spreadsheet used for the analysis responded to the following categories:

1. Marker of reification: lack of differentiation (all Muslims are the same);

2. Positive/negative/neutral tone;

3. Marker of Banal Islamophobia: identifying Muslims with particular racial (race, skin tone) or visual (hijab; abaya) traits, habits, or attitudes;

4. Marker of Banal Islamophobia: depiction of Islam/Muslims as different (from "us");

5. Marker of Banal Islamophobia: expressions referring to the "re-education" of Muslims;

6. Marker of Banal Islamophobia: expressions referring to "Good Muslims" and "Bad Muslims";

7. Marker of Ontological Islamophobia: identifying Islam/Muslims with violence/terrorism/ fanaticism;

8. Marker of Ontological Islamophobia: explicit mention of the impossibility of coexistence.

If reification and a negative tone are retrieved, the content is marked as Islamophobic and, to be ascribed to a specific type of Islamophobia, it must contain at least one of the markers related to one of the two types of Islamophobia. If an article contains markers of both Banal and Ontological Islamophobia, it is marked as "mixed".

\section{Results}

\subsection{Quantitative Analysis}

Islam is a much-discussed topic in all the analyzed media: the most retrieved words are Islamic, followed by Islam. Interestingly Muslim(s) is the lesser used word. In the overall period, the newspapers dedicate an average of 3.5 articles per day to the topic.

All the analyzed media show similar trends in terms of quantity of content, although left-leaning La Repubblica and especially El País dedicate more space to Islam-related topics.

As Figure 1 displays, in terms of chronological distribution, the attention towards Islam and Muslims depends on the development of terrorism-related current events. As Figure 1 displays, Islam-related content was higher in 2015 and 2016, especially coinciding with the Charlie Hebdo and Bataclan terrorist attacks in 2015, and with the Brussels bombings and the Nice truck attack in 2016. In Italian newspapers, the quantity of articles starts decreasing in 2017 while, in Spain, there is a peak coinciding with Barcelona's attack in August 2017.

A common trend can also be observed in the number of articles per section. Islam and Muslims are almost uniquely mentioned in hard news, mainly in international current affairs, followed by national and local news. Soft news articles related to culture, society, etc. represent a small minority, with left-leaning media dedicating some more space (see Figure 2). 


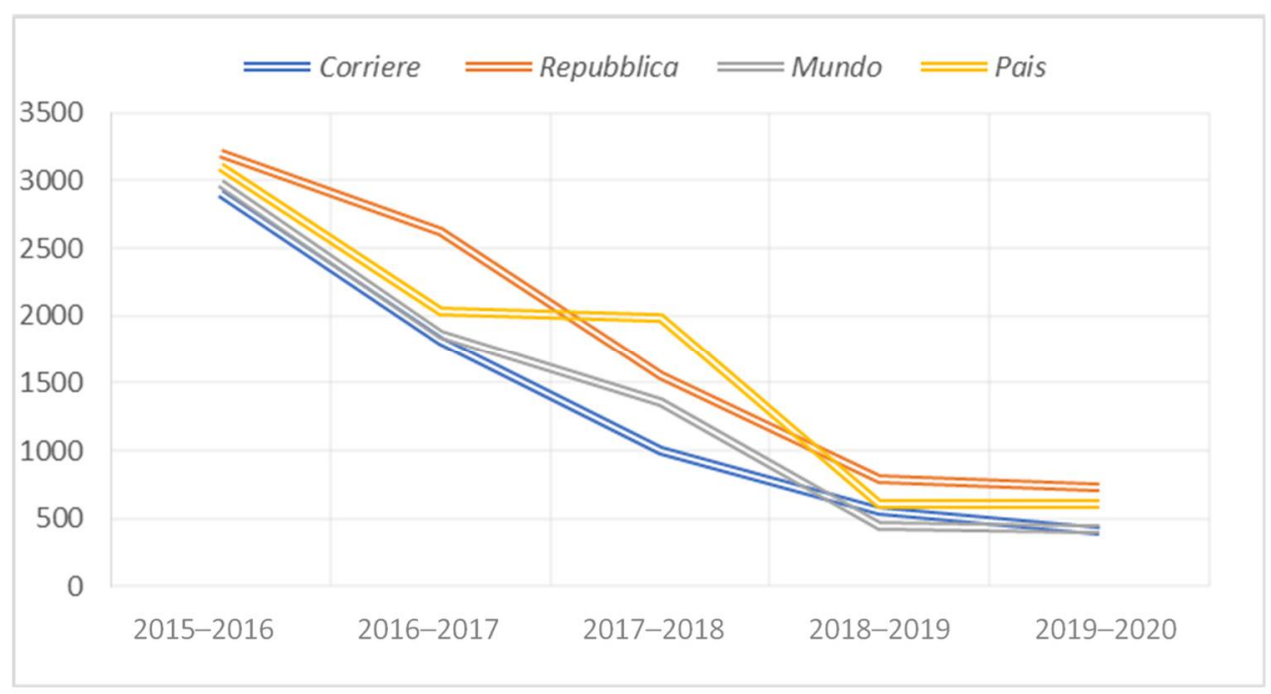

Figure 1. Chronological distribution of content containing Islam-related keywords. Source: elaborated by the authors.

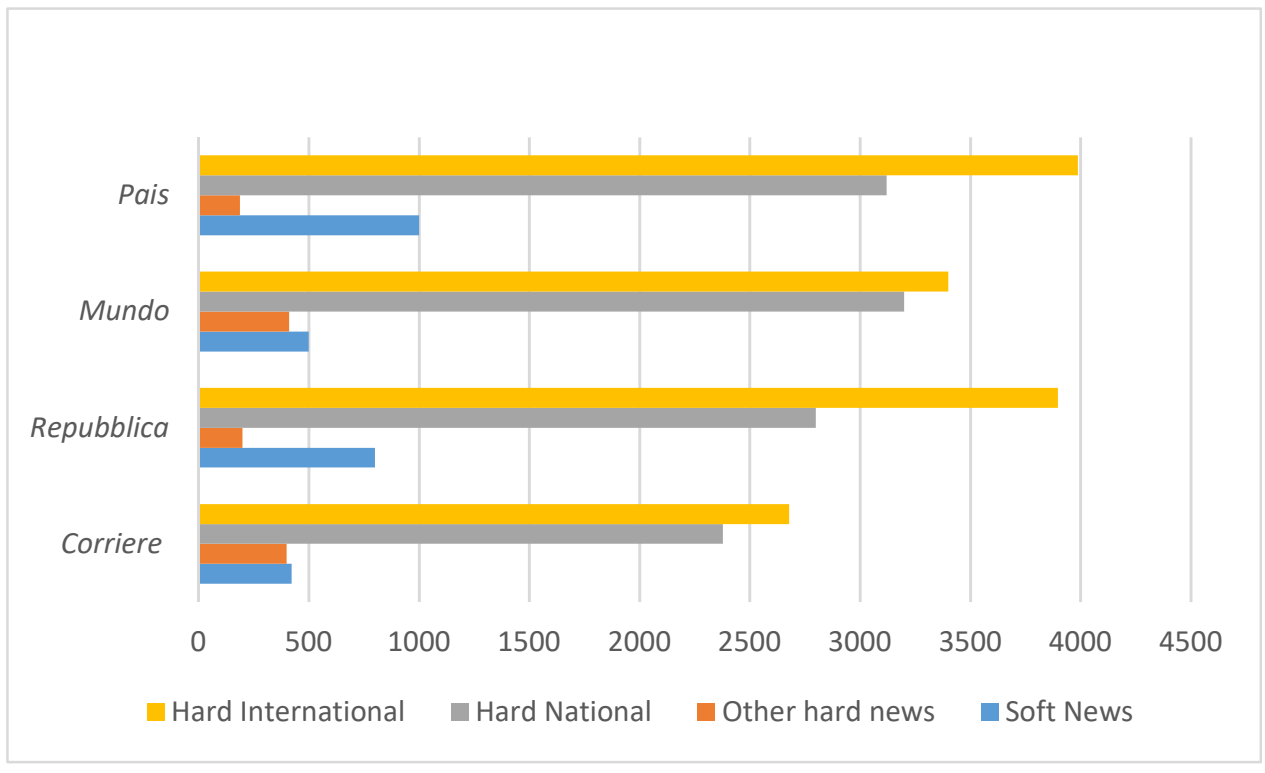

Figure 2. Distribution per news genre. Source: elaborated by the authors.

As for the most recurrent topics (see Figure 3), an overwhelming majority of pieces mentioning Islam/Muslims are related to terrorism. That is to say that they explicitly mention terrorism.

Of note is that, while Italian media use the definition "Islamic terrorism" in $87.8 \%$ of cases, Spanish media alternatively use the expression or terms related to "jihad" (jihadism, jidadist, jihadi terrorism).

Terrorism is mostly discussed in international hard news in Italy $(70.6 \%$ of the retrieved articles belong to this category) while, in Spain, the distribution is even between international and national news (51.4\% and $49.6 \%$, respectively).

The second recurrent topic is "radicalization", mostly appearing in national and local news in all the media, and especially connected to immigration and the "problem" of integration.

Looking at words' distribution, as illustrated in Table 1, it is possible to highlight that the most frequently mentioned geographical place in all the analyzed media is Syria, 
followed by each newspaper's home country and different terrorism-related locations, such as France, Paris Germany, or the Middle East.

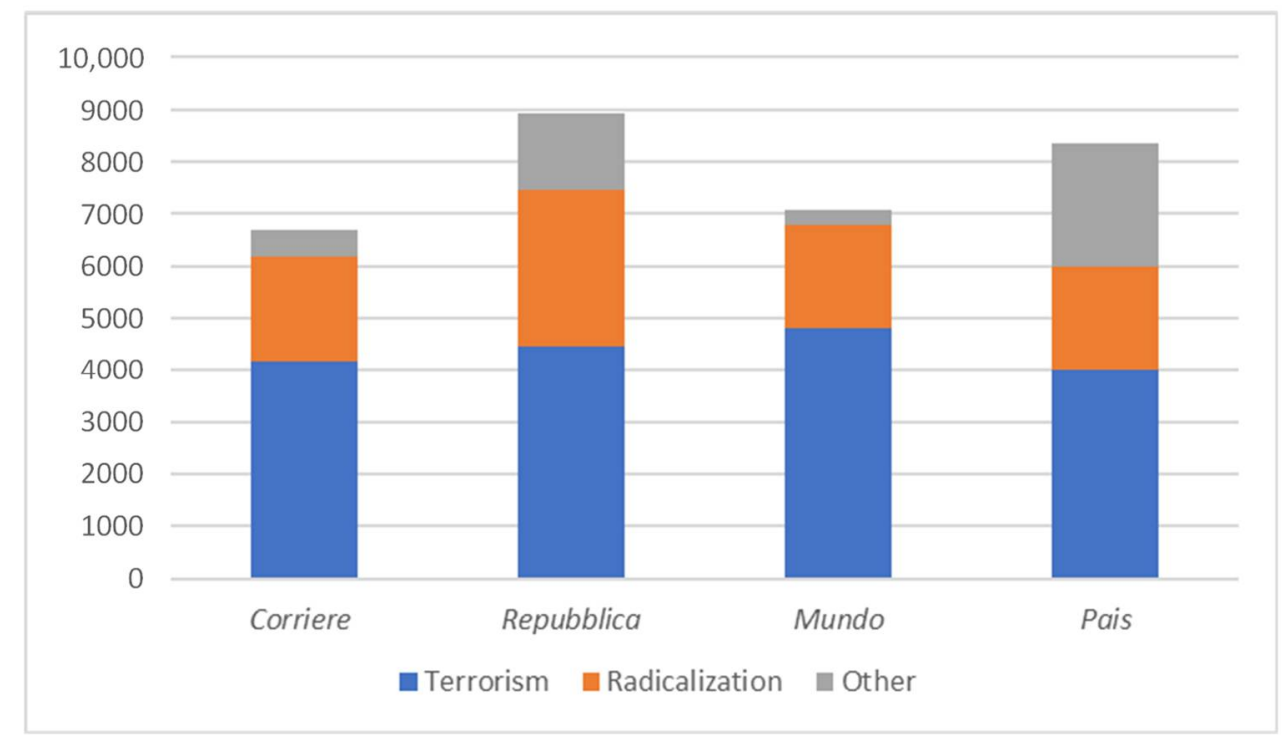

Figure 3. Most recurrent topics. Source: elaborated by the authors.

Table 1. Words distribution.

\begin{tabular}{|c|c|c|c|}
\hline Newspaper & Most Mentioned Places & $\begin{array}{l}\text { Most Mentioned } \\
\text { Organizations }\end{array}$ & Most Mentioned Individuals \\
\hline Il Corriere della Sera & $\begin{array}{c}\text { Siria (356); Italy (264); France (231) } \\
\text { Paris (215); Europe (200); USA (198); } \\
\text { Iraq (150); Germany (121); Middle } \\
\text { East (113); UK (88) }\end{array}$ & $\begin{array}{l}\text { Charlie Hebdo (165); Al Qaeda } \\
\text { (158); UN (138); Isis (133); EU } \\
\text { (89); Facebook (94); Twitter (69) }\end{array}$ & $\begin{array}{c}\text { Matteo Salvini (123); Pope } \\
\text { Francis (98); Maometto } \\
\text { (Muhammad) (87); Donald } \\
\text { Trump (78) Barack Obama (72); } \\
\text { Osama Bin Laden (57); Hillary } \\
\text { Clinton (32); Matteo Renzi (29) } \\
\text { Magdi Cristiano Allam (21); } \\
\text { Vladimir Putin (19) }\end{array}$ \\
\hline La Repubblica & $\begin{array}{l}\text { Siria (300); Italy (264); France (247) } \\
\text { Paris (235); Europe (190); Roma (180) } \\
\text { USA (168); Iraq (150); Germany (121); } \\
\text { Middle East (113) }\end{array}$ & $\begin{array}{l}\text { Charlie Hebdo (145); Al Qaeda } \\
\text { (107); UN (101); EU (98); Isis } \\
\text { (89); Al Qaeda (82); Facebook } \\
\text { (76); Twitter (62) }\end{array}$ & $\begin{array}{l}\text { Donald Trump (161); Barack } \\
\text { Obama (142); Papa Francesco } \\
\text { (98) Matteo Salvini (97); Angela } \\
\text { Merkel (78); Matteo Renzi (57) } \\
\text { Osama Bin Laden (47); Abu } \\
\text { Bakr (45) Saddam Hussein (34) }\end{array}$ \\
\hline El País & $\begin{array}{l}\text { Siria (387); Spain (301); France (247) } \\
\text { Barcelona (212); Europe (190); } \\
\text { Israel (180) } \\
\text { USA (145); Palestine(131); Germany } \\
\text { (121); Raqqa (113) }\end{array}$ & $\begin{array}{c}\text { Charlie Hebdo (185); Al Qaeda } \\
\text { (147); UN (131); EU (121); Isis } \\
\text { (100); Al Qaeda (92); Police (86); } \\
\text { Interpol (62) }\end{array}$ & $\begin{array}{l}\text { Barack Obama (154); Donald } \\
\text { Trump (147); Hillary Clinton } \\
\text { (138) Angela Merkel (128); } \\
\text { Bashar Asad (120) Osama Bin } \\
\text { Laden (97) Al Bagdadi (94) }\end{array}$ \\
\hline El Mundo & $\begin{array}{c}\text { Siria (300); Spain (264); } \\
\text { Barcelona (247) } \\
\text { USA (225); Paris (193); Europe (181) } \\
\text { Israel (155); Palestine (150); Germany } \\
\text { (121); Madrid (113) }\end{array}$ & $\begin{array}{l}\text { Charlie Hebdo (145); Al Qaeda } \\
\text { (107); UN (101); Police (99); EU } \\
\text { (98); Isis (89); Al Qaeda (82); } \\
\text { CIA (74); Mossad (65) }\end{array}$ & $\begin{array}{l}\text { Donald Trump (177); Barack } \\
\text { Obama (154); Hillary Clinton } \\
\text { (138) Angela Merkel (128); } \\
\text { Bashar Asad (120) Osama Bin } \\
\text { Laden (97) Al Bagdadi (94) }\end{array}$ \\
\hline
\end{tabular}

Source: elaborated by the authors.

Interestingly, while both Spanish newspapers often frame Islam within the IsraeliPalestinian conflict, it is not mentioned in Italy. 
The findings on most recurrently mentioned organizations confirm the previous consideration: the most mentioned organization in all the newspapers is the French newspaper Charlie Hebdo, followed by international institutions such as the UN or the European Union and terrorist organizations such as Al Qaeda or IS (named ISIS both in Spanish and Italian). In Italy, social networks such as Facebook and Twitter also appear on the list.

As for individuals, we observe an overwhelming presence of American politicians in all the newspapers.

In Italy, Matteo Salvini, leader of the populist rightwing Lega party, well known for anti-Muslim opinions (Cervi 2020), emerges as the most quoted public figure (above anyone else) in Corriere della Sera and amongst the most quoted in Repubblica, showing this party's ability to set the media agenda. In particular, Il Corriere della Sera gives a wide voice to Magdi Cristiano Allam, an Egyptian Muslim and former journalist turned politician who converted to Catholicism, and who is well known for his criticism of Islam. On the contrary, in Spain, the Vox party is hardly ever mentioned by either newspaper.

Moreover, both Italian news outlets frequently mention and quote the Pope in their discussions of Islam. No Islamic religious authority is retrieved; nonetheless, Il Corriere della Sera quotes Prophet Muhammad 87 times.

\subsection{Qualitative Analysis}

The results reveal a strong presence of Islamophobic content in both Italian and Spanish media. Italian newspapers comparatively show the highest rates of Islamophobia (an average of 75\% for $1 l$ Corriere della Sera and an average of 70\% for La Repubblica). Spanish newspapers, on their side, display the highest differences, with El País containing the lowest (average 60\%) and El Mundo the highest (88\%) amount of Islamophobic content.

In this sense, while Ghauri and Umber's (2019) thesis on the difference between conservative and left-leaning newspapers can be confirmed in Spain, with El Mundo being the first in terms of Islamophobic content and El País being the last, in Italy, the results of both newspapers are very similar.

As per the type of Islamophobia, a general trend is apparent throughout all the analyzed newspapers: Ontological Islamophobia is prevalent in all the media when reporting about international affairs (see Figure 4).

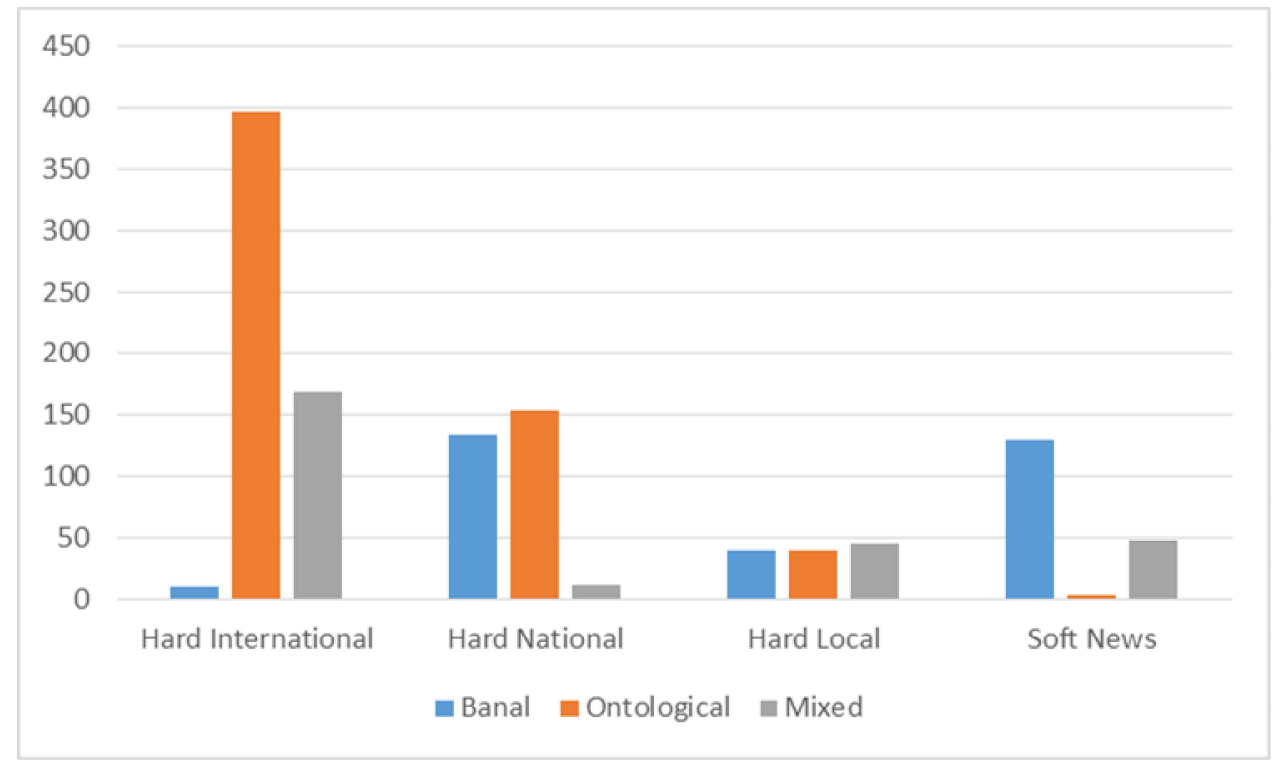

Figure 4. Type of Islamophobic content per section. Source: elaborated by the authors.

In particular, within hard international news, terrorism seems to be the ideal trigger for Ontological Islamophobia. When reporting about terrorist attacks, or anything related to terrorism, all the newspapers tend to represent Islamic civilization as a monolithic 
"world apart", characterized by violence and thus irremediably irreconcilable with Western civilization.

Although the "clash of civilization" is never openly mentioned, many headlines openly allude to this alleged clash.

In an article that appeared in left-leaning La Repubblica in 2016, Brussels is openly defined as "Bruxellistan" and "a world apart".

"Bruxellistan: un mondo a parte chiamato Molenbeek"

("Brusselistan: another planet called Molenbeek". Raffaele Oriani, La Repubblica.

7th March 2016)

In this regard, a difference can be observed: Italian newspapers dedicate more time and words to the issue of "foreign fighters" than Spanish newspapers. Particularly interesting is the narrative surrounding the story of is Maria Giulia Sergio, an Italian girl who converted to Islam and fled to Syria to fight with IS, and was re-named by journalists of both newspapers as "Lady Jihad".

After the publication of a police telephone tapping of a conversation between Maria Giulia and her family used in her trial, both newspapers published the content (both as transcript and audio), either underlining the level of radicalization, in terms of intention to cause harm, or indirectly ridiculing the issue by stressing specific parts of the conversation. When the girl tried to convince her family to join her in the alleged jihad, her mother's main concern seemed to be whether IS would provide her with at least a little garden to grow vegetables; she also wondered how they were going to transport the family's pet dog to Syria.

"Le intercettazioni, Maria Giulia Sergio: Papà prendi mamma per i capelli e vieni in Siria"

("The telephone tapping: Daddy, grab mommy by her hair and come to Syria" La Repubblica, 2nd July 2015)

In both national and local hard news, Islam dominated the headline in content related to "radicalization; in this regard, the difference between left-leaning and conservative newspapers becomes evident. While conservative newspapers tend to refer to radicalization related to the impossibility of living together, thus displaying Ontological Islamophobia, left-leaning newspapers show a higher level of Banal Islamophobia, mostly related to the distinction between moderate and "radical" Muslims.

While the conservative El Mundo, for instance, provocatively asks what a president of a polling station would hide behind her burqa, clearly alluding to the relationship between a certain garment and terrorism, La Repubblica praises the example of integration of a Muslim young man who has joined the Carabinieri (Italian police) Corps.

"Lo que esconde la presidenta con 'burka' de la mesa electoral"

("What the burqa- president hides" Lucas De La Cal and Ángeles Escrivá, El Mundo, 2nd June 2019)

"Islam e divisa un carabiniere di nome Badar"

("Islam and Uniform: a Carabiniere named Badar"Cristina Palazzo, La Repubblica, 23 June 2019)

As for soft news, in general, this type of content display higher degrees of Banal Islamophobia, mostly concerning Islamic traditions (Ramadan, butchering habits, etc.). In left-leaning newspapers in both countries, in particular, most of the retrieved pieces refer to women's headscarves. La Repubblica especially dedicates many articles to the female veil, framing it as oppressive towards women.

"Islam, la sfida delle ragazze"

("Islam, a challenge for girls". Francesca Caferri, La Repubblica. 25th May 2018)

Conservative media, on their side, tend to display more mixed Islamophobia. 
"Machismo, represión y homofobia: asífueron mis tres meses de experimento en Tinder en un país musulmán "

("Sexism, repression, and homophobia: my three months experiment on Tinder in a Muslim country". Lucas De La Cal, El Mundo, 7th October 2017)

Seeing this clear relationship between hard news, especially in pieces related to terrorism, and Islamophobic content, it does not surprise us that Islamophobic content has decreased over time (see Figure 5).

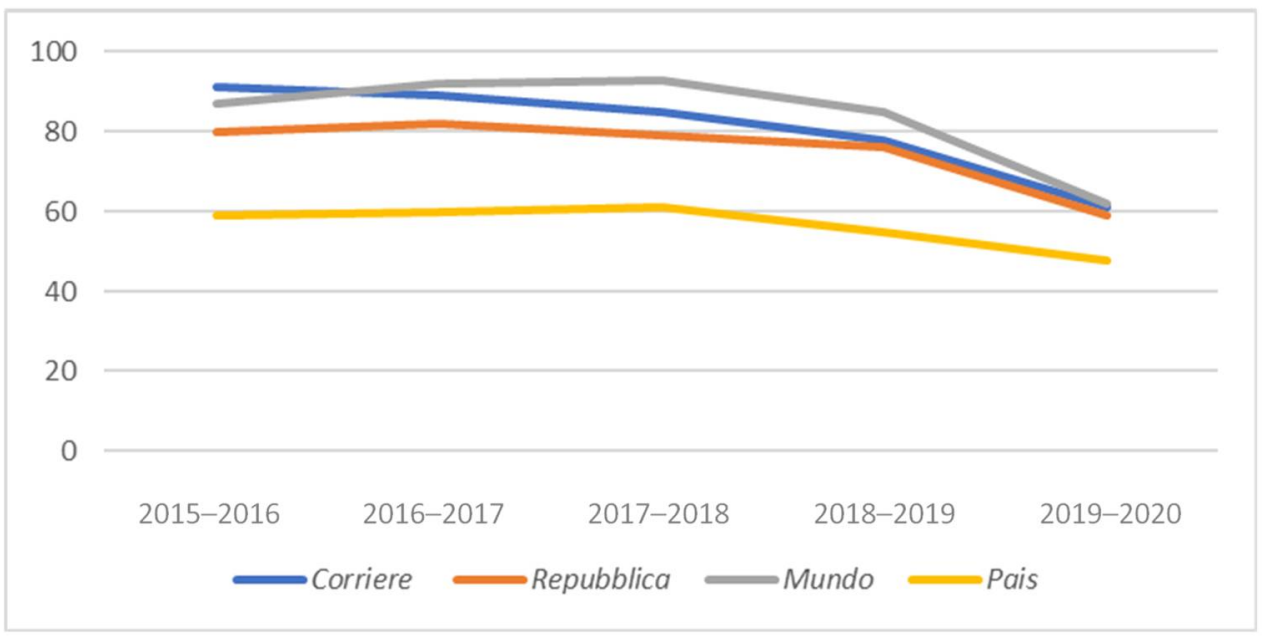

Figure 5. Chronological distribution of Islamophobic content. Source: elaborated by the authors.

Regarding the specific categories of Islamophobic messages, Figure 6 illustrates how Ontological Islamophobia is mainly represented by the construction of the relationship between Islam and terrorism. Both countries' conservative newspapers, especially the Spanish El Mundo, also often openly refer to the impossibility of coexistence between Muslims and non-Muslims, which is a claim that is very scarce in left-leaning newspapers.

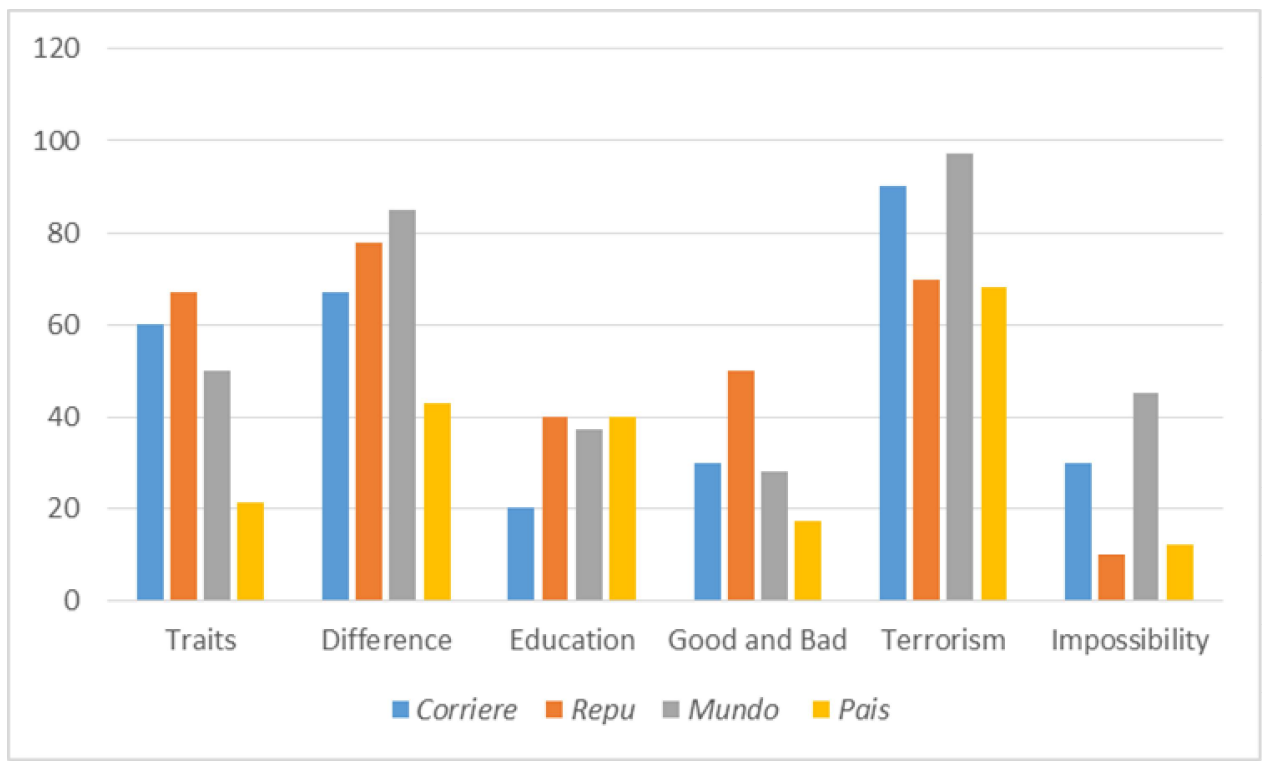

Figure 6. Categories of Islamophobic message. Source: elaborated by the authors.

The second most frequent category is the one marking a difference between the Western "us" and the Muslim "other", followed by the reification of Muslims according to racial or visual (for women mostly veil) traits. In this case, El País stands out for 
not focusing on visual traits but proportionally focusing more on the stereotype of the possibility/opportunity of re-educating Muslims.

Finally, as Figure 7 shows, there is a big difference between headlines and texts, with headlines showing a greater amount of explicit Islamophobia. Overwhelmingly, an overall $89.7 \%$ of the headlines use Islamophobic language.

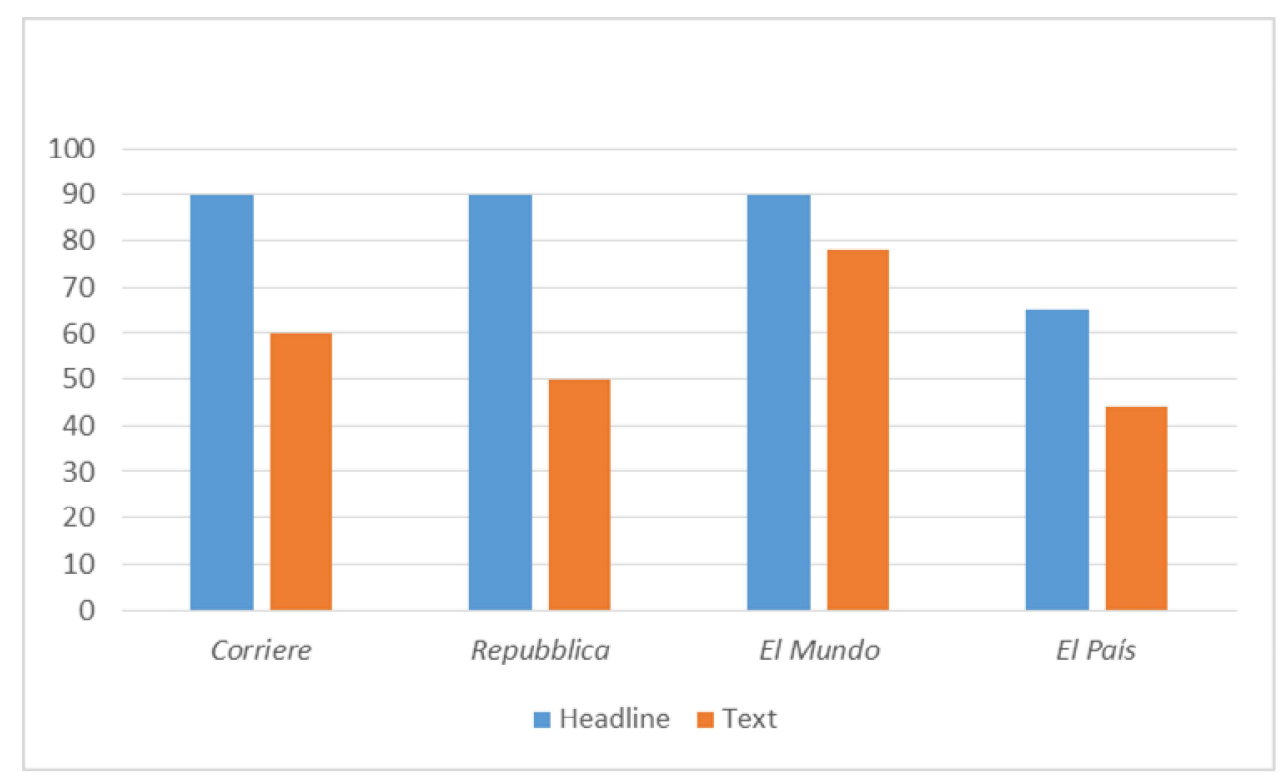

Figure 7. Headlines and texts. Source: elaborated by the authors.

In some cases, a headline is explicitely Islamophobic while the text is not. In the following article, "Torino: festa al Condominio Ramadan, le case popolari dove gli immigrati sono maggioranza" (Gabriele Guccione, La Repubblica, 11st July 2016), for example, the headline says "Turin: Celebration at the Ramadan Building, where immigrants are the majority", while the text explores and praises a successful case of integration.

This finding suggests a positive correlation between sensation-seeking headlines and Islamophobia.

While not the core of our article, our qualitative analysis confirms the difference between the two countries regarding the coverage of populist right-wing parties. While, in Spain, the presence of Vox has a modest influence on the negative portrayal of Muslims in both newspapers, in the Italian Corriere della Sera, $85 \%$ of the articles referring to the Muslim presence in the country also contain the words "Matteo Salvini", leader of the Islamophobic Lega party. This latter point shows how this party has monopolized the immigration agenda, especially regarding Muslims and how it has negatively influenced the way they are portrayed. La Repubblica displays a lower correlation; however, whenever Salvini is given voice, some kind of Islamophobic content appears.

\section{Conclusions and Discussion}

Our results confirm previous findings showing that Islamophobia is predominant in media portrayals of Islam and Muslims in Italy and Spain.

In particular, our findings corroborate that terrorism dominates the information on Islam and Muslims and, although the difference in Italy is minimal, they align with Ghauri and Umber's (2019) hypothesis that conservative media tend to depict Islam more negatively.

However, further research should expand the analysis to a broader set of newspapers and to other countries to test this correlation.

Furthermore, our analysis contributes to the burgeoning literature about media representations of Islam and Muslims, underlining that headlines tend to enclose more Is- 
lamophobic content than articles themselves, and suggesting that sensationalism, if not click-baiting, might be the primary source of misrepresentation.

On the other side, our method and the distinction between two types of Islamophobia offer new insights into understanding how Islam and Muslims are viewed within Western societies, allowing us to conclude that "Ontological Islamophobia", especially in rightleaning newspapers, emerges when dealing with international or domestic terrorism, while, when Muslims are portrayed within the narration of immigration or integration, we encounter more "Banal Islamophobia".

In both cases, Muslims are presented as "others" who, in the case of Ontological Islamophobia, are incompatible with Western values and, in Banal Islamophobia, can be integrated only if they renounce their "barbaric" habits to embrace modernity and (Western) civility.

Along the same lines, our analysis has shown that, within the sources interpellated to talk about Islam (the Pope, politicians, etc.), Muslim sources are hardly ever mentioned. As such, since most Muslims are not in Europe but there are European Muslims, the media should grant them the opportunity to express their diverse voices.

Finally, yet importantly, in Italy, the correlation between increased media coverage of radical right-wing populist parties and the negative representation of Muslims appears evident, but this is not confirmed in Spain.

In this case, it is important to stress that, while Salvini's party is well established and successful (Tarchi 2015), and Salvini himself was Minister of the Interior in 2018, Vox is a new party which has recently irrupted in the political system. Accordingly, future comparative research should be geared towards testing this hypothesis.

Author Contributions: Conceptualization, L.C.; Data curation, S.T.; Funding acquisition, M.G.; Methodology, L.C.; Project administration, S.T.; Software, M.G.; Supervision, S.T.; Validation, M.G.; Visualization, S.T.; Writing-original draft, L.C. All authors have read and agreed to the published version of the manuscript.

Funding: This research received no external funding.

Informed Consent Statement: Not applicable.

Data Availability Statement: Not applicable.

Conflicts of Interest: The authors declare no conflict of interest.

\section{References}

Ahmed, Saifuddin, and Jörg Matthes. 2017. Media representation of Muslims and Islam from 2000 to 2015: A meta-analysis. International Communication Gazette 79: 219-44. [CrossRef]

Alcaraz, Antonia, and Malia Politzer. 2020. Islamophobia in the Spanish Press: An analysis of the media coverage of the Charlie Hebdo attacks. Estudios sobre el Mensaje Periodistico 26: 253.

Alietti, Alfredo, and Dario Padovan. 2013. Religious racism: Islamophobia and antisemitism in Italian society". Religions 4: 584-602. [CrossRef]

Allen, Chris. 2010a. Islamophobia. London: Ashgate.

Allen, Chris. 2010b. Fear and loathing: The political discourse in relation to Muslims and Islam in the contemporary British setting. Contemporary British Religion and Politics 2: 221-36.

Allen, Chris. 2020. Towards a Working Definition: Islamophobia and Its Contestation. In Reconfiguring Islamophobia. Edited by Christopher Allen. London: Palgrave, pp. 1-13.

Allievi, Stefano. 2006. How the Immigrant has become Muslim. Public debates on Islam in Europe. Revue Européenne des Migrations Internationales 21: 135-63. [CrossRef]

Baker, Paul, Costas Gabrielatos, and Tony McEnery. 2013. Discourse Analysis and Media Attitudes. The Representation of Islam in the British Press. Cambridge: Cambridge University Press.

Balibar, Etienne. 1991. Racism and Nationalism. In Race, Nation, Class: Ambiguous Identities. Edited by Etienne Balibar and Immanuel Wallerstein. London: Verso.

Bayrakli, Enes, and Farid Hafez. 2020. European Islamophobia Report 2019. Istanbul: SETA.

Bazeley, Pat. 2010. Computer assisted integration of mixed methods data sources and analysis. In SAGE Handbook of Mixed Methods in Social E Behavioral Research, 2nd ed. Edited by A. Tashakkori and C. Teddlie. Thousand Oaks: Sage. 
Beccaro, Andrea, and Stefano Bonino. 2019. Terrorism and Counterterrorism: Italian Exceptionalism and Its Limits. Studies in Conflict $\mathcal{E}$ Terrorism 2019: 1-18. [CrossRef]

Bleich, Erik. 2011. What Is Islamophobia and How Much Is There? Theorizing and Measuring an Emerging Comparative Concept. American Behavioral Scientist 55: 1581-600. [CrossRef]

Bleich, Erik, and A. Maurits van der Veen. 2018. Media portrayals of Muslims: A comparative sentiment analysis of American newspapers, 1996-2015. Politics, Groups, and Identities 9: 20-39. [CrossRef]

Bleich, Erik, Hasher Nisar, and Cara Vazquez. 2018. Investigating status hierarchies with media analysis: Muslims, Jews, and Catholics in The New York Times and The Guardian headlines, 1985-2014. International Journal of Comparative Sociology 59: 239-57. [CrossRef]

Boomgaarden, Hajo G., and Rens Vliegenthart. 2007. Explaining the rise of anti-immigrant parties: The role of news media content. Electoral Studies 26: 404-17. [CrossRef]

Boomgaarden, Hajo. G., and Rens Vliegenthart. 2009. How news content influences anti-immigration attitudes: Germany, $1993-2005$. European Journal of Political Research 48: 516-42. [CrossRef]

Bowe, Brian J., Shaira Fahmy, and Jorg Matthes. 2015. Moving Beyond the Religion Next Door: Valence in News Framing of Islam. Newspaper Research Journal 36: 42-57. [CrossRef]

Bravo López, Fernando. 2011. Towards a definition of Islamophobia: Approximations of the early twentieth century. Ethnic and Racial Studies 34: 556-73. [CrossRef]

Bravo López, Fernando. 2016. Islamophobia. In The Wiley-Blackwell Encyclopedia of Race, Ethnicity and Nationalism. Edited by John Stone, Rutledge M. Dennis, Polly Rizova, Anthony D. Smith and Xiaoshuo Hou. Oxford, Malden and Chichester: Wiley-Blackwell. [CrossRef]

Carr, James, and Amanda Haynes. 2015. A Clash of Racializations: The Policing of 'Race' and of Anti-Muslim Racism in Ireland. Critical Sociology 41: 21-40. [CrossRef]

Cesari, Jocelyne. 2010. Securitization of Islam in Europe. In Muslims in the West after 9/11: Religion, Politics, and Law. Edited by Jocelyne Cesari. London: Routledge, pp. 9-27.

Cesari, Jocelyne. 2011. Islamophobia in the West: A comparison between Europe and the United States. In Islamophobia: The Challenge of Pluralism in the 21st Century. Edited by John Esposito and İbrahim Kalın. Oxford: Oxford University Press, pp. 21-42.

Cervi, Laura. 2019. Similar Politicians, Different Media. Media Treatment of Sex Related Scandals in Italy and the USA. Medijske studije 10: 161-79. [CrossRef]

Cervi, Laura. 2020. Exclusionary Populism and Islamophobia: A Comparative Analysis of Italy and Spain. Religions 11: 516. [CrossRef]

Cervi, Laura, and Núria Roca. 2017a. Towards an Americanization of political campaigns? The use of Facebook and Twitter for campaigning in Spain, USA and Norway. Anàlisi 87: 7-100. [CrossRef]

Cervi, Laura, and Núria Roca. 2017b. La modernización de la campaña electoral para las elecciones generales de España en 2015. ¿Hacia la americanización? Comunicación y Hombre 13: 133-50. [CrossRef]

Cervi, Laura, and Santiago Tejedor. 2020. S. Framing “The Gypsy Problem”: Populist Electoral Use of Romaphobia in Italy (2014-2019). Social Sciences 9: 105. [CrossRef]

Cervi, Laura, and Santiago Tejedor. 2021. “Toda África no cabe en Europa": Análisis comparativo de los discursos de los partidos anti inmigración en España y en Italia. Migraciones. Publicación Del Instituto Universitario De Estudios Sobre Migraciones 51: 207-39. [CrossRef]

Colombo, Monica. 2018. The Representation of the "European Refugee Crisis" in Italy: Domopolitics, Securitization, and Humanitarian Communication in Political and Media Discourses. Journal of Immigrant \& Refugee Studies 16: 161-78. [CrossRef]

Corbin, Caroline Mala. 2017. Terrorists Are Always Muslim but Never White: At the Intersection of Critical RaceTheory and Propaganda. Fordham Law Review 86: 455. Available online: https:/ /irlawnet.fordham.edu/flr/vol86/iss2/5 (accessed on 2 June 2021).

Corral, Alfonso, Cayetano Fernández Romero, and Carmela García Ortega. 2020. Framing \& islamophobia. Spanish reference press coverage during the Egyptian Revolution (2011-2013) (2011-2013). Revista Latina de Comunicación Social 77: 373-92. [CrossRef]

Flood, Christopher, Steven Hutchings, Galina Miazhevich, and Henry Nickels. 2012. Islam, Security and Television News. Basingstoke: Palgrave.

Ewart, Jaqui, Kate O'Donnell, and April Chrzanowski. 2018. What a difference training can make: Impacts of targeted training on journalists, journalism educators and journalism students' knowledge of Islam and Muslims. Journalism 19: 762-81. [CrossRef]

Garner, Steve, and Saher Selod. 2015. The Racialization of Muslims: Empirical Studies of Islamophobia. Critical Sociology 41: 9-19. [CrossRef]

Ghauri, Muhammad Junaid, and Salma Umber. 2019. Exploring the Nature of Representation of Islam and Muslims in the Australian Press. SAGE Open 9. [CrossRef]

Gould, Rebecca Ruth. 2019. The Limits of Liberal Inclusivity: How Defining Islamophobia Normalises Anti-Muslim Racism. Journal of Law and Religion 35: 250-69. [CrossRef]

Halliday, Fred. 1999. 'Islamophobia' reconsidered. Ethnic and Racial Studies 22: 892-902. [CrossRef]

Huntington, Samuel. 1996. The Clash of Civilizations and the Remaking of World Order. New York: Simon and Schuster.

Imhoff, Roland, and Julia Recker. 2012. Differentiating Islamophobia: Introducing a New Scale to Measure Islamoprejudice and Secular Islam Critique. Political Psychology 33: 811-24. [CrossRef] 
Khader, Bichara. 2016. Reflexiones sobre la islamofobia 'ordinaria'. Afkar Ideas 50: 16-18.

Krippendorff, Klaus. 2004. Reliability in content analysis. Human Communication Research 30: 411-33. [CrossRef]

Larsson, Göran, and Simon Stjernholm. 2016. Islamophobia in Sweden: Muslim Advocacy and Hate-Crime Statistics. In Fear of Muslims? International Perspectives on Islamophobia. Edited by Douglas Pratt and Rachel Woodlock. Heidelberg and New York: Springer, pp. 153-66. [CrossRef]

Larsson, Göran, and Åke Sander. 2015. An Urgent Need to Consider How to Define Islamophobia. Bulletin for the Study of Religion 44: 13-17. [CrossRef]

Lorente, Javier Rosón. 2010. Discrepancies around the Use of the Term "Islamophobia". Human Architecture: Journal of the Sociology of Self-Knowledge 8: 11.

Malik, Kenan. 2009. From Fatwa to Jihad: The Rushdie Affair and Its Legacy. London: Atlantic Books.

Mamdani, M. 2004. Good Muslim, Bad Muslim. America, the Cold War and the Roots of Terror. New York: Pantheon Books.

Marusek, Sarah. 2018. Inventing terrorists: The nexus of intelligence and Islamophobia. Critical Studies on Terrorism 11: 65-87. [CrossRef]

Marzano, Arturo. 2011. Reading the Israeli Palestinian conflict through an Islamophobic prism: The Italian press and the Gaza war. Journal of Arab and Muslim Media Research 4: 63-78. [CrossRef]

Merolla, Jennifer, S. Karthick Ramakrishnan, and Chris Haynes. 2013. "Illegal," "Undocumented," or "Unauthorized": Equivalency frames, issue frames, and public opinion on immigration. Perspectives on Politics 11: 789-807. [CrossRef]

Munnik, Michael B. 2017. From voice to voices: Identifying a plurality of Muslim sources in the news media. Media, Culture $\mathcal{E}$ Society 39: 270-81. [CrossRef]

Newman, Nic, Richard Fletcher, David. A. L. Levy, and Rasmus K. Nielsen. 2016. Reuters Institute Digital News Report 2016. Oxford: Reuters Institute for the Study of Journalism.

Nickerson, Connor. 2019. Media portrayal of terrorism and Muslims: A content analysis of Turkey and France. Crime, Law and Social Change 72: 547-67. [CrossRef]

Observatorio de la Islamofobia. 2018. Una Realidad Incontestable: Islamofobia en los Medios. Available online: https://www.iemed. org/publicacions-es/historic-de-publicacions/coedicions/una-realidad-incontestable-islamofobia-en-los-medios (accessed on 2 June 2021).

Özyürek, Esra. 2005. The politics of cultural unification, secularism, and the place of Islam in the new Europe. American Ethnologist 32: 509-12. [CrossRef]

Pew Research Center. 2019. In the U.S. and Western Europe, People Say They Accept Muslims, but Opinions are Divided on Islam. Available online: https: / / pewrsr.ch/2IxucPY (accessed on 2 June 2021).

Rafi, Muhammad Shaban. 2020. Dialogic Content Analysis of Misinformation about COVID-19 on Social Media in Pakistan. Linguistics and Literature Review 6: 131-43. [CrossRef]

Ragozina, Sofya. 2020. Constructing the image of Islam in contemporary Russian print media: The language strategies and politics of misrepresentation. Religion, State and Society 48: 22-37. [CrossRef]

Richards, Barry, and Lorraine Brown. 2017. Evidence and ideology: Moderating the critique of media Islamophobia. Journalism Education 6: 12-22.

Richardson, Robin. 2009. Islamophobia or anti-Muslim racism-Or what? Concepts and terms revisited. Paper presented at the Conference on Islamophobia and Religious Discrimination: New Perspectives, Policies and Practices, Birmingham, UK, December 9. Available online: http:/ / www.insted.co.uk/anti-muslim-racism.pdf (accessed on 2 June 2021).

Riffe, Daniel, Stephen Lacy, and Frederick Fico. 2014. Analyzing Media Messages: Using Quantitative Content Analysis in Research, 3rd ed. New York: Routledge.

Runnymede Trust. 1997. Islamophobia: A Challenge for Us All. London: Runnymede Trust.

Said, Edward W. 1978. Orientalism. New York: Pantheon Books.

Salaita, Steven George. 2006. Beyond orientalism and Islamophobia-9/11, anti-Arab racism, and the mythos of national pride. CR: The New Centennial Review 6: 245-66. [CrossRef]

Saleem, Muniba, Sara Prot, Craig. A. Anderson, and Anthony. F. Lemieux. 2017. Exposure to Muslims in media and support for public policies harming Muslims. Communication Research 44: 841-69. [CrossRef]

Samaie, M., and B. Malmir. 2017. US news media portrayal of Islam and Muslims: A corpus-assisted Critical Discourse Analysis. Educational Philosophy and Theory 49: 1351-66. [CrossRef]

Sayed, A., and A. Ibrahim. 2018. Recent developments in systematic sampling: A review. Journal of Statistical Theory and Practice 12: 290-310. [CrossRef]

Sayyid, S. 2018. Islamophobia and the Europeanness of the Other Europe. Patterns of Prejudice 52: 420-35. [CrossRef]

Sunar, Lufti. 2017. The Long History of Islam as a Collective "Other" of the West and the Rise of Islamophobia in the U.S. after Trump. Insight Turkey 19: 35-52. Available online: http:/ /www.jstor.org/stable/26300529 (accessed on 17 January 2021). [CrossRef]

Tarchi, Marco. 2015. Italy: The promised land of populism? Contemporary Italian Politics 7: 273-85. [CrossRef]

Tejedor, Santiago, Laura Cervi, Fernanda Tusa, Marta Portales, and Margarita Zabotina. 2020. Information on the COVID-19 Pandemic in Daily Newspapers' Front Pages: Case Study of Spain and Italy. International Journal of Environmental Research and Public Health 17: 6330. [CrossRef]

Testa, Alberto, and Gary Armstrong. 2012. We Are Against Islam! SAGE Open 2: 1-14. [CrossRef] 
Turnbull-Dugarte, Stuart. J. 2019. Explaining the end of Spanish exceptionalism and electoral support for Vox. Research and Politics 6. [CrossRef]

van Dijk, Teun A. 1987. Mediating racism: The role of the media in the reproduction of racism. In Language, Power and Ideology: Studies in Political Discourse. Edited by R. Wodak. Amsterdam: Benjamins, pp. 199-222.

Younes, Zein Bani, Isyaku Hassan, and Mohd Nazri LatiffAzmi. 2020. A Pragmatic Analysis of Islam-related Terminologies in Selected Eastern and Western Mass Media. Arab World English Journal 11: 70-84. [CrossRef] 